\title{
BEYOND GENTRIFICATION: DIVERSIFIED NEIGHBOURHOOD UPGRADING IN THE INNER CITY OF BUDAPEST
}

\begin{abstract}
KOVÁCS, Z., WIESSNER, R., ZISCHNER, R. (2015): Beyond gentrification: Diversified neighbourhood upgrading in the inner city of Budapest. Geografie, 120, No. 2, pp. 251-274. - The concept of gentrification has been extensively used in post-socialist context in association with neighbourhood renewal processes, despite the exact meaning of the term and its social effects not always being sufficiently clarified. This paper builds upon empirical research from downtown Budapest. Our investigation primarily focused on the interplay of three groups of stakeholders involved in urban renewal: politicians, investors and residents. On the basis of our multi-dimensional analysis, we could identify three main types of upgrading: classical gentrification (with two sub-types), as well as incumbent upgrading and soft forms of revitalisation. In the studied neighbourhoods, a mixture of these forms of upgrading could be identified, reflecting a diversified rejuvenation. Gentrification was spatially limited to poverty ridden neighbourhoods subject to local government organised regeneration programmes. The predominance of soft forms of revitalisation is a function of housing market mechanisms as well as the planning control of local districts, which in general together create a healthy social mix despite pervasive regeneration activities.

KEY WORDS: gentrification - urban regeneration - segregation - social-mix - post-socialist cities.

This research was supported by a grant from the Deutsche Forschungsgemeinschaft (DFG) and the Hungarian Scientific Research Fund (OTKA) Grant Agreement No. K 105534, "Spatial Pattern of Post-socialist Urbanisation in Hungary".
\end{abstract}

\section{Introduction}

Due to its highly diversified housing stock, its multi-faceted segregation pattern and not least the pace and complexity of recent multiple transformations (Sýkora, Bouzarovski 2012), Budapest has been increasingly in the focus of urban research. Several aspects of urban transformations have been intensely discussed, the most frequented topics range from the consequences of economic restructuring and globalisation (Barta et al 2006; Földi, van Weesep 2007), to the transformation of real-estate market and its effects on the built environment (Hegedüs, Tosics 1994; Kovács, Wiessner 1999; Tosics 2005; Kauko 2007), to the new waves of residential mobility, including suburbanisation (Beluszky, Timár 1992; Kok, Kovács 1999; Timár, Váradi 2001; Dövényi, Kovács 2006), as well as the evolving new pattern of social segregation (Ladányi 2002, Tosics 2006, Kovács 2012). On the neighbourhood level, the transformation of innercity quarters with their rapidly changing functional and social milieu has 
also attracted great attention. While early studies revealed the socio-economic decline and marginalisation of some of these neighbourhoods (Ladányi 1993; Kovács 1998), more recent publications shed light on various forms of physical and social upgrading as a result of spontaneous (market-led) and local government initiated renewal programmes (Földi 2006; Kovács 2009; Kovács, Wiessner, Zischner 2013). More or less simultaneously dynamic upgrading processes were also reported from the inner cities of other post-socialist cities like Prague (Sýkora 1999), Vilnius (Standl, Krupickaite 2004), Riga (Krišjāne, Bērziñš 2014), Warsaw (Górczyńska 2014) and Moscow (Badyina, Golubchikov 2005) where the return of the new middle class to previously impoverished inner-city quarters gained gradually momentum and signs of population change became widespread. This is not surprising, as perhaps the most visible and abrupt changes having taken place in post-socialist cities over the last two decades were concentrated in the city centres where the contest for space among investors, developers and affluent residents was the strongest. Despite the growing body of literature, we know very little about the mechanisms and the role of various protagonists of these early-stage gentrification (?) processes. Therefore, this paper aims to analyse the mechanisms of city centre's renaissance in the inner part of Budapest in the light of the interplay of three main groups of stakeholders: politicians, investors and residents. The paper is divided into five parts. In the first, the concept of gentrification is revisited with special reference to its adaptability in post-socialist context. It is followed by the introduction of research methodology. In the third section the influencing factors of urban renewal in downtown Budapest are elucidated. In the fourth section a typology of neighbourhood renewal is outlined. Finally, the concluding section summarises the main research findings and sets further research questions.

\section{The concept of gentrification and its post-socialist applicability}

\subsection{Gentrification as a catch all term}

The term gentrification was first coined by sociologist Ruth Glass (1964) to describe "a process of class based neighbourhood change in a handful of London neighbourhoods like Islington" (Hammel 2009, p. 360). In these neighbourhoods poor working class residents were displaced by a new class called "gentrifiers" consisting of well-educated and better off people. Their appearance resulted in improvements in the area's housing stock and public infrastructure with a subsequent increase of dwelling prices and rents (Hammel 2009). Over the last five decades there has been a shift in meaning and the term gentrification has been used in the literature in many different ways and the critique of a chaotic concept is more than ever timely (Beauregard 1986). Terms like "rural gentrification" (Phillips 1993, 2002, 2005), "new-build gentrification" (Davidson, Lees 2005, 2010; Rérat, Lees 2011), "marginal gentrification" (Rose 1996; van Criekingen, Decroly 2003) or "super-gentrification" (Hammel 2009) broadened the concept of gentrification aggregating very diverse social processes under 
a single label, some of them even referring to locations outside the inner city (Lees, Slater, Wyly 2008).

Studying the process of gentrification some authors put the emphasis on physical upgrading which is not necessarily followed by an influx of better off people and an increase of real estate prices (Smith 1996). This is for instance the case when the renovation of buildings is carried out by long-term residents and is not coupled by population displacement, a process what was named "incumbent upgrading" (Clay 1979). As a contrast, others use the term of "gentrification" exclusively for social upgrading processes and according to their view a physical upgrading in the neighbourhood is not necessary (see Friedrichs 1996, Glatter 2007). The shifts in meaning over the last five decades reflect the gradual change that has evolved in gentrification research as far as the forms, actors and geographical locations of the process are concerned. As a consequence, gentrification has gradually become a catch all term used to describe a great variety of social and physical urban transformation processes (Atkinson, Bridge 2005; Lees, Slater, Wyly 2008; Rérat, Söderström, Piguet 2010). This is not least because our cities are affected by a wide range of interrelated physical and social changes, resulting from the growing differentiation of lifestyle and housing demand of residents, creation of new leisure or tourist infrastructure, the proliferation of actors and institutions contributing to urban renewal.

The concept of gentrification has also been extensively used in the study of urban transformations in Central and Eastern Europe (CEE) where urban renewal brought about spectacular changes after 1990. Although the term was first used for Budapest by Hegedüs and Tosics (1991), it was Eastern Germany (the former GDR) where comprehensive regeneration programmes reshaped many inner-cities causing market-based gentrification processes (Bernt, Holm 2005, 2009; Friedrich 2000; Glatter 2007; Weiske 1996). In these cities the renovation of old inner-city housing stock commenced earlier and run faster than in other post-socialist countries because of central-state subsidies and massive capital (partly speculative) flow from Western Germany. As a consequence of robust investment an oversupply of renovated housing on the housing market arose which in turn set strong limitations to possible price and rent increase. Consequently, lower income groups (e.g. students, elderly) continued to have access to the renovated housing stock of the inner-city neighbourhoods, hence the process was labelled as "soft" gentrification or "delayed" gentrification (see Zischner 2003; Hill, Wiest 2004; Wiest, Zischner 2006).

East German cities were followed by other major (mostly capital) cities of the more developed northern part of CEE on the way of inner-city upgrading and gentrification (Földi 2006; Kovács 2009; Marzińczak 2012; Murzyn 2006; Standl, Krupickaite 2004; Sýkora 1999). Studies focusing on physical and social changes of inner-city neighbourhoods in the region have reported unequivocally the presence of gentrification, however, it has not always been clear what process is exactly meant by gentrification, what are its socio-economic contexts and if the described processes are comparable with those of the western cities. Given the substantial differences in socio-economic conditions and planning regimes between east and west the question comes to the fore, if we can really talk about a "post-socialist gentrification"? 


\subsection{Explanations of gentrification}

There are basically two major strands of explanations focusing either on the supply or the demand side of gentrification. Among the supply-oriented explanations the well-known rent-gap theory (Smith 1979, 1996) and its European adaptation the value-gap theory can be distinguished (see Hamnett, Randolph 1986; Musterd, Ostendorf, eds. 1998).

Partly as a critique of any kind of supply-oriented explanations a fundamentally different approach to gentrification appeared in the 1980s putting emphasis on the demand side of the process (see Ley 1980, 1981). The demandoriented explanation links gentrification to larger political and economic forces that help create a new class of potential gentrifiers. According to this concept gentrification is generated by the growing number of young and better off households, who follow an inner-city orientated lifestyle and create a considerable demand for high quality dwellings in inner-city neighbourhoods. The inner-city orientation of this new class is partly the result of their employment in the urban core and in part a change of their cultural values with regard to liveability and urban aesthetics.

Taking into account the various forms of gentrification and the diversification of lifestyles in contemporary urban societies the participants of inner-city upgrading and gentrification have in the meantime also become socially more heterogeneous. Based on empirical results Karsten (2003) for instance pointed out the participation of young families with children in the process of gentrification, what was labelled as "family gentrification". Therefore, we argue that it is necessary to analyse the demand side more thoroughly and to take sociocultural indicators in addition to socio-economic ones more into consideration.

In addition to the demand- and supply-oriented concepts many studies have emphasised that inner-city renewal and more specifically gentrification cannot be considered, at least under European conditions, solely a market generated process because public sector, local politics and planning also contribute to its appearance (Wiessner 1987, 1988; Dangschat 1988; Carpenter, Lees 1995; Ley 1996; Friedrichs, Häussermann 2001; Bernt, Holm 2009; Holm 2006; Kovács, Wiessner, Zischner 2013; Breckner 2010; Twickel 2010; Wiessner, Zischner 2010). The influence of public sector in inner-city upgrading is very broad and it can range from subsidies provided for urban regeneration programmes, through local renewal strategies, to direct interventions on the housing market like privatisation and/or restitution of public housing sector as it happened in the CEE countries in the early 1990s. The influence of public sector can also vary greatly among cities depending on the national and local political contexts; therefore, it is no wonder that urban renewal processes and gentrification show great variations not just among countries but also among cities. The same is true for the intraurban level, if the public administration of a city is decentralised and boroughs and districts are relatively independent (like as it is in Budapest) a great diversity of neighbourhood change can be observed in the city.

Based on these observation, we follow a multidimensional approach in our research (Fig. 1) where the interplay of political, economic and social factors (see also Zukin 1982, Dangschat 1988, Lees 1994) contributing to urban renewal and 


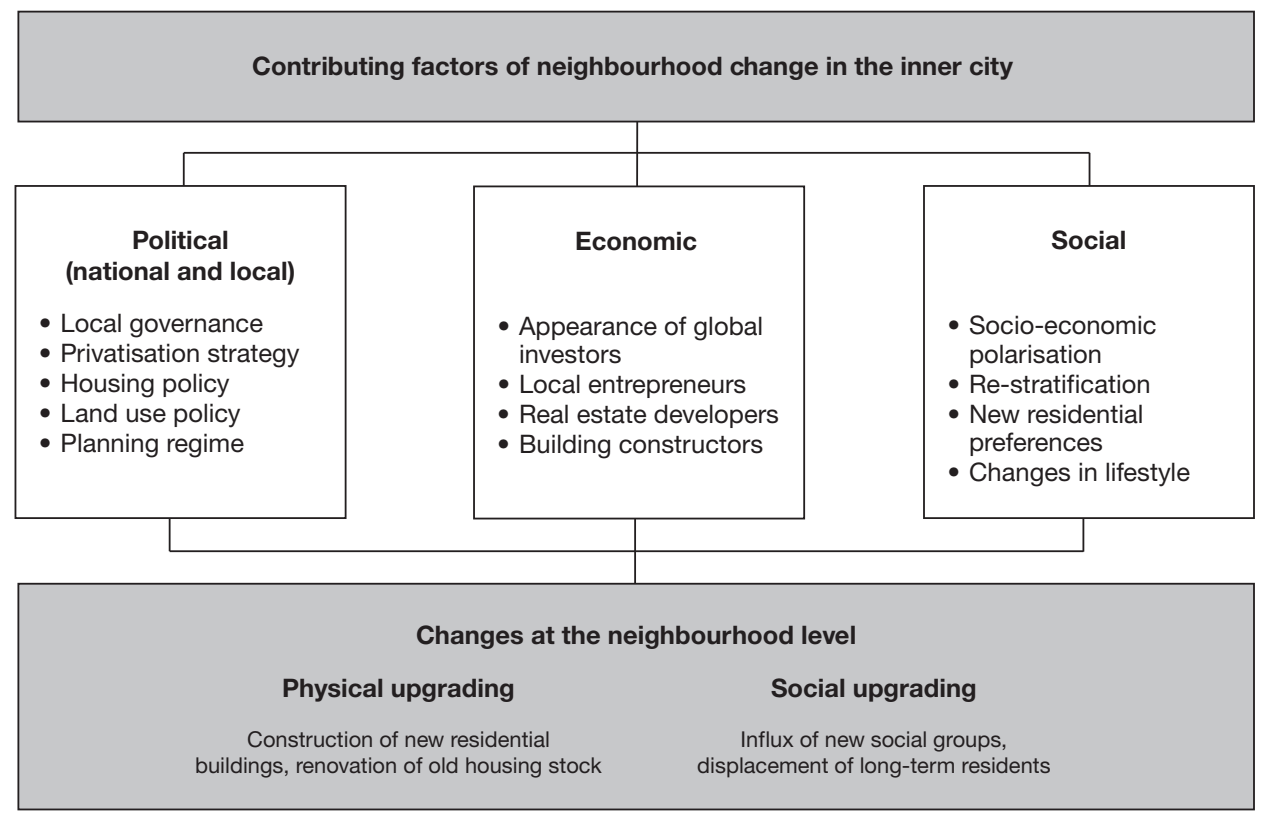

Heterogeneous trajectories of upgrading

Fig. 1 - Conceptual framework of neighbourhood change in post-socialist cities.

Source: Zischner (2013).

neighbourhood change in Budapest as well as local framework conditions will be systematically analysed and confronted. Obviously, as there is no universal model for upgrading and gentrification (Lees 2003, Ley 2003, Atkinson, Bridge 2005) we assume that even within Budapest there are different development trajectories of inner-city neighbourhoods because of the highly differentiated framework conditions at the local level (Zischner 2013).

\section{Research design and empirical data}

This paper is based on empirical data collected in an international research project focusing on the physical and social transformation in the inner city of Budapest. The main objective of the project was to record the extent of neighbourhood change that have evolved in the centre of the city after 1990 and to provide explanation for the upgrading processes with special attention to the role of public and private actors.

As a first step a mapping survey covering 10,534 buildings in the historical districts of Budapest was carried out in July 2005, where physical parameters as well as the functional use of the buildings were recorded. This survey enabled us to identify seven smaller case-study neighbourhoods where either signs 


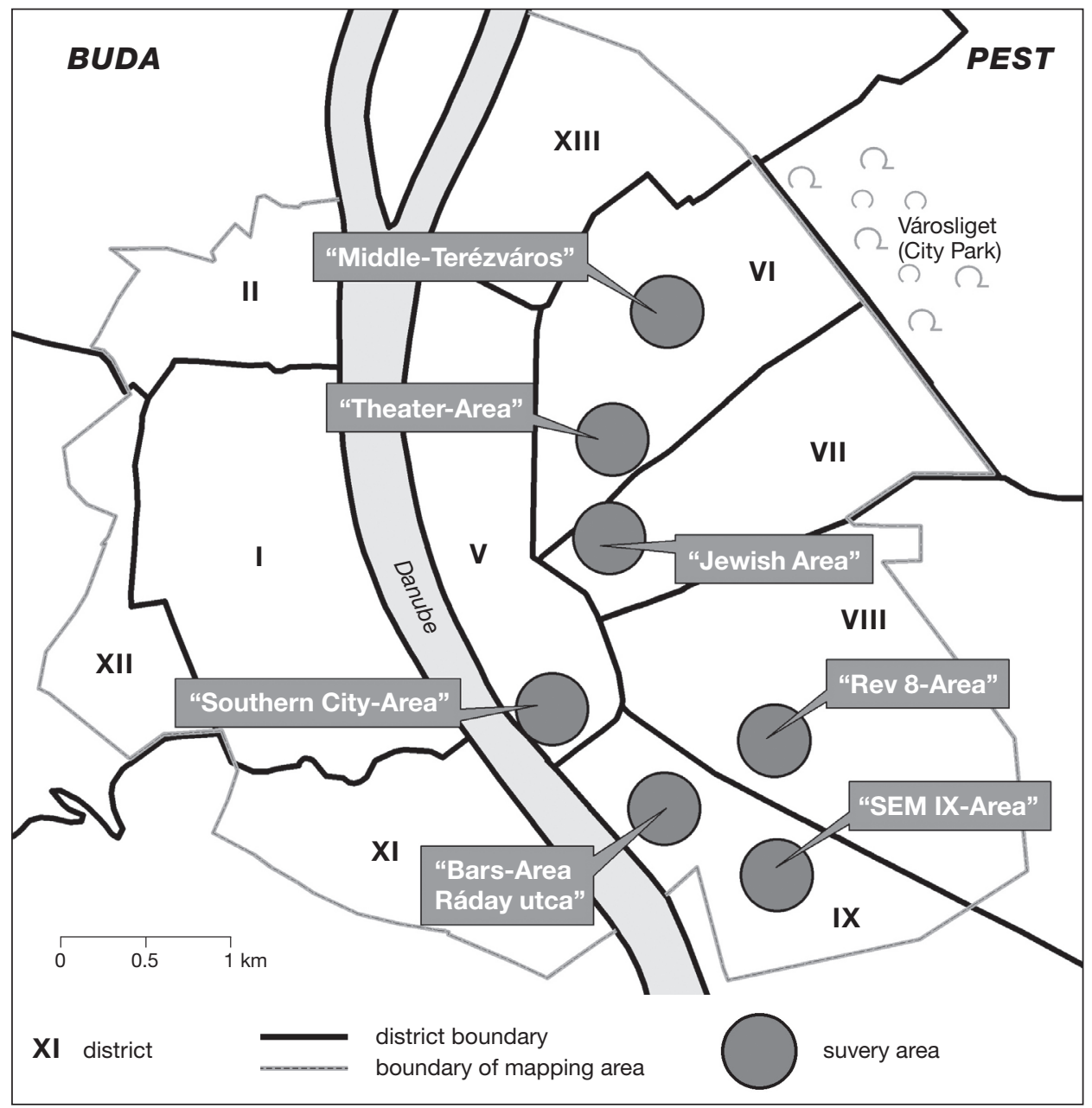

Fig. 2 - Mapping and survey area, Budapest - Inner city

of intense physical upgrading or functional changes hinted at the presence of urban renewal and the possible occurrence of gentrification. In these neighbourhoods a detailed questionnaire survey was carried out among residents in 2006, focusing on the renewal activities of households, their housing career, and housing preferences. Altogether 1,234 households were selected in the case-study neighbourhoods for questionnaire survey out of which 503 were successfully completed (41\%). Although the response rate was somewhat lower than in previous surveys (see e.g. Kovács, Wiessner 1999), yet, data provided us an opportunity to make generalisations about the attitude of residents in upgrading neighbourhoods at least according to two broad categories: newcomers and long-term residents.

Figure 2 shows the mapping area and the seven small-scale survey areas. We must note that the seven case-study areas are located in five different 


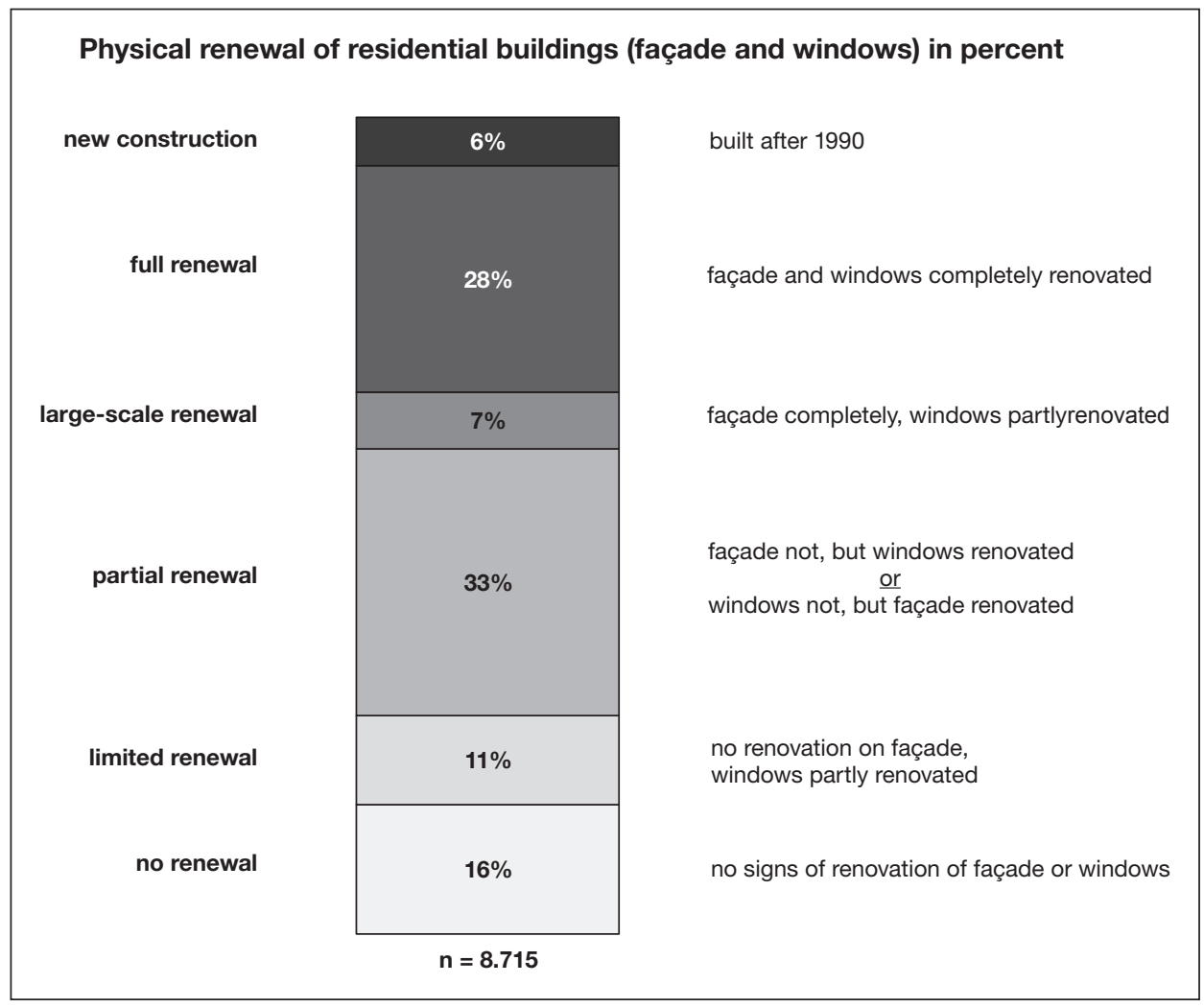

Fig. 3 - Extent of physical renewal of residential buildings (facade and window) in the inner city of Budapest, 2005 July. Source: mapping survey.

inner-city districts each having a democratically elected local government with high-degree of autonomy.

In addition to the surveys, in-depth interviews with selected households (2-3 in each neighbourhood, altogether 18) were carried out to collect deeper information about the mobility and lifestyle of different household-types. Moreover, semi-structured in-depth interviews with local experts and stakeholders both at the city and district levels (altogether 12) were carried out to find out the attitude of different actors (investors, local government) in the process of neighbourhood renewal. Data of Figure 3 show that urban renewal had become a dominant trajectory in downtown Budapest by the middle of the first decade of 2000 s.

For the sake of analysis we refer here only to data for buildings which have a predominantly $(50 \%+)$ residential use. Our data show that 6 percent of the buildings were built and a further 28 percent were fully renovated after 1990 , which means that about one third of the building stock in the inner city of Budapest was affected by substantial physical renewal during the first fifteen years of post-socialism. If we also add those cases where the façade was completely renovated ("large-scale renewal") the intensity of renewal activity in the inner 
city of Budapest is unexpectedly high with over 40 percent of all cases. Since urban renewal is fairly uneven in space we could easily select those pockets of the inner city (seven survey areas shown on Figure 2) where the upgrading was most pronounced and the occurrence of gentrification was most likely.

\section{Influencing factors of urban renewal and their effects in Budapest}

According to our conceptual framework (see Fig. 1) improvements to the built environment in post-socialist cities can be best explained by the configuration of three sets of interrelated factors: political, economic and social. Their role may differ from city to city, or even from neighbourhood to neighbourhood, yet they should be carefully taken into account when dealing with any sign of neighbourhood renewal in post-socialist cities. In this section the effects of these factors and the motivations of actors in Budapest downtown are introduced in the light of our empirical findings.

\subsection{Political factors}

Disinvestment or reinvestment in urban space highly depends on politics (Smith 1996). From the political side the reshuffle of public administration system, shifts in housing policy and the proliferation of urban renewal policies of local districts had utmost importance in the transformation of inner-city neighbourhoods in Budapest.

Firstly, one of the basic preconditions of post-socialist urban transformation in CEE was the return to self-governance. In the case of Budapest a two-tier administrative system was introduced and considerable part of the decisionmaking power was shifted from city to district level. The districts as administrative units enjoy high level of autonomy in implementing housing and social policies, drawing regulation plans etc. As a consequence, in Budapest the 23 districts became the main agencies of urban development after 1990.

Secondly, regarding market-based urban renewal and possible gentrification the liberalisation of the housing market, more specifically the privatisation of public housing was an important prerequisite. On the eve of the political changes housing was owned predominantly (95-97\%) by the state in the inner districts of Budapest. After 1990, as part of the political changes, local governments (in Budapest individual districts) became the owners of the public housing stock. Though the rules of housing privatisation was centrally set ("give-away privatisation" to sitting tenants at a very low price) districts enjoyed great freedom as far as the extent and pace of privatisation were concerned. They could formulate their own housing privatisation policies. Given the general lack of resources, the newly established district governments were in most cases eager to carry out an excessive privatisation in order to reduce social subsidies and generate income. This practice, in addition to no restrictions on resale of the dwelling, made the privatisation of public housing, especially the best quality dwellings in desirable locations very attractive due to the considerable value 
gap (Kovács 2009). The very liberal system of housing privatisation together with the fragmented local government structure resulted in substantial differences at the district and neighbourhood level as far as opportunities for urban renewal were concerned.

Thirdly, the legal framework of urban regeneration was practically missing in Budapest in the first half of the 1990s. The newly established local governments lacked the necessary resources and the private sector had hardly any interest in the renewal of residential buildings (Hegedüs, Tosics 1994). From the mid-1990s, however, the legal and financial framework of urban renewal was gradually elaborated. In 1994 the Act on Condominiums solved the problem of blocks of flats (often with mixed tenure), giving them a firm legal status. In 1996 the official urban revitalisation programme of Budapest was elaborated by the Budapest Municipality. Consolidation of the legal framework resulted in mushrooming of local policies, strategies and initiatives aiming at urban renewal at different scales.

The chances of regeneration tended to depend very much on the size of the local public housing stock, the quantity of empty plots and abandoned sites where local governments could initiate new housing projects (Földi 2006). On the basis of interviews with local experts we could define three distinct types of Budapest districts according to their willingness and success in launching and implementing renewal programmes. The first group included those two rather dilapidated districts - most notably Ferencváros (District IX) and Józsefváros (District VIII) - which were among the first to formulate clear strategies for urban regeneration and initiated large-scale area based renewal programmes during the 1990s providing best practices for other districts. According to our typology these two districts followed active strategy for urban revitalisation (Kovács, Wiessner, Zischner 2013). In both districts, a large part of the public housing stock remained in state ownership providing the local government enough room for intervention. In addition, both districts were rich in vacant plots and abandoned (brownfield) sites which made large-scale intervetions easier. These two districts established special revitalisation companies on a PPP basis (SEM IX in Ferencváros, and Rév8 in Józsefváros, see Figure 2) in the 1990s that took responsibility for, and coordinated the process of comprehensive regeneration in certain pockets of their respective districts. Through these companies local government could actively keep control over the renovation of old housing stock. Private developers in these neighbourhoods had very limited opportunity to set their foot.

In the second group of districts the revitalisation process was less systematically organised, nevertheless, it has been in one way or another supported by local government measures. We called this attitude as "limited support for urban revitalisation» strategy (Kovács, Wiessner, Zischner 2013). Among the investigated neighbourhoods the following examples could be identified. In the "Theatre Quarter" (District VI) the upgrading was enhanced by local infrastructure development (reconstruction of street surface and development of pedestrian zones) and promotion of local cultural institutions in order to increase the attractiveness of the neighbourhood. In "Middle-Terézváros" (District VI) a public programme was launched for the renovation and conversion of lofts. Thirdly, in the "Bar Quarter" in District IX the increasing tourists 
flow to Budapest and the growing demand for catering facilities enhanced the development of a bar and restaurant quarter. Similarly to District VI local authorities supported the private initiatives with additional investments e.g. renovation of road surface, pedestrianisation etc. The above mentioned examples are typically long-established bourgeois neighbourhoods inhabited mainly by elderly households. In these neighbourhoods buildings are usually renewed by the local condominiums. Renovations are scattered in the area, and external private investors play only a limited role in the process e.g. through sporadic new-build housing projects.

The attitude of other districts in the inner city of Budapest regarding urban renewal has been rather passive and they relied very much on market forces. We called this type of local government strategy as "hands off approach" (Kovács, Wiessner, Zischner 2013). This fits well to the "Southern City Area" in District V, where the main priority of local government has been retail and business development as opposed to the renewal of residential buildings. Renewal of housing is also difficult here because the overwhelming majority of public dwellings became privatised soon after the change of regime. In general, the hands off approach is typical among districts where the social status of residents is traditionally high, and where the renewal of buildings is a self-generating process due to the dominance of privately owned flats and the relatively high demand towards these flats on the market. This applies very much to inner-city neighbourhoods located on the posh Buda side of the city.

Despite its relatively good opportunity for intervention the attitude of District VII (Erzsébetváros) has also been characterised by a hands off approach. Our case study area in this district was the "Jewish Quarter". The local government here followed a very liberal laissez faire urban policy, and provided great opportunities for private investors. During the 1990s vacant sites gradually disappeared in the neighbourhood, first they were built up by office, later by residential buildings. By the early 2000s hardly any empty plot remained for new construction, therefore, demolition of existing buildings started. In this process several buildings with great architectural value were torn down, and subsequently the architectural milieu, just like the social profile of the neighbourhood changed dramatically.

\subsection{Economic factors}

In a competitive market economy new urban development is geared to maximize profit: landlords, realtors, developers, and even local homeowners equally have incentives to use a particular plot or building for the most profitable function possible (Lees, Slater, Wyly 2008). For some location economically optimal use will be high-end retail, leisure or office, for others upmarket middle class housing. After privatisation a very competitive real estate market emerged in Budapest as prices increased and geographically became differentiated. The "functional gap" (i.e. the mismatch between urban core land uses under statesocialist conditions, see Sýkora 1999) was quickly exploited by new forms of land use, commercialisation and functional conversion driven mostly by global capital (Földi, van Weesep 2007; Kovács, Wiessner 1999; Kovács 2009). Foreign 
Table 1 - Segments of housing market in the survey area

\begin{tabular}{|lcr|}
\hline Segment of housing market & $\begin{array}{c}\text { Number } \\
\text { of dwellings }\end{array}$ & Percent \\
\hline Old housing stock (built before 1989) & 410 & 83 \\
public rental dwelling & 51 & 10 \\
private rental dwelling & 36 & 7 \\
owner occupied dwelling, obtained by privatisation & 216 & 44 \\
owner occupied dwelling, purchased on the market & 107 & 22 \\
\hline New housing stock (built 1989 or later) & 85 & 17 \\
private rental dwelling & 14 & 3 \\
owner occupied dwelling & 71 & 14 \\
Missing values for 8 dwellings & & 100 \\
\hline Altogether & 495 & \\
\hline
\end{tabular}

Source: household survey 2006 (Zischner 2013)

Table 2 - Intensity of renovation of dwellings in the survey area

\begin{tabular}{|lccccc|}
\hline Old housing stock & \multicolumn{3}{c}{ Level of renovation } & & $\mathrm{n}$ \\
\cline { 2 - 5 } & $\begin{array}{c}\text { largely } \\
\text { reno- } \\
\text { vated } \\
\text { (built before 1989) }\end{array}$ & $\begin{array}{c}\text { partially } \\
\text { reno- } \\
\text { vated } \\
\%\end{array}$ & $\begin{array}{c}\text { hardly } \\
\text { reno- } \\
\text { vated } \\
\%\end{array}$ & & \\
\hline Public rental dwelling & 20 & 53 & 27 & $100 \%$ & 49 \\
$\begin{array}{l}\text { Private rental dwelling } \\
\text { Owner occupied dwelling, }\end{array}$ & 28 & 58 & 14 & $100 \%$ & 36 \\
obtained by privatisation & 21 & 69 & 11 & $100 \%$ & 208 \\
Owner occupied dwelling, & 53 & 42 & 5 & $100 \%$ & 100 \\
purchased on the market & & & & & \\
Missing values for 23 dwellings & & & & & \\
\hline Altogether & 30 & 59 & 11 & $100 \%$ & 393 \\
\hline
\end{tabular}

Source: household survey 2006 (Zischner 2013)

capital was present in the city well before the political changes but the intensity of such investments gained momentum with the liberalisation of the economy and the revival of real estate market after 1990 (Kauko 2007). According to Földi and van Weesep (2007) global capital can generate changes in the residential environment in two distinct ways: through direct and indirect means. It works, on the one hand, via direct investments (i.e. new-build gentrification); and on the other hand, it has an indirect effect through the construction of commercial or office developments, giving a signal to professional housing developers that the neighbourhood is worthy of their attention. In Budapest the indirect effect has been more pronounced until now. The functional use of innercity neighbourhoods has been transformed gradually due to commercialisation and globalisation. The economic restructuring and the subsequent take-off of the service sector has induced a growing demand for non-residential (business, office etc.) space and contributed to the physical upgrading and functional 
change of the city-centre (Kovács 2009). However, direct investments of foreign capital on the housing market have remained limited. Our survey data show that nearly half (44\%) of the dwellings in the inner city was obtained through privatisation and they were inhabited by the first owners (Table 1). Another 10 percent of the housing stock was owned by the districts and served as public rentals. Thus, these two segments were excluded from market transactions and the possible influence of private (foreign) investors. Only two segments of the local housing stock could have relations with private investors: (1) the "new housing stock" (17\%), and (2) that part of the "old housing stock" (22\%) which was sold on the market by the new owners after privatisation ${ }^{1}$. As buyers on the secondary market are usually individuals searching for home for their own use, or for their kids, private investors had more importance in the newly built housing stock than institutional developers.

Homeowners became also interested in renovating their buildings utilising the lucrative opportunities provided by the existence of value-gap. Our survey data indicate that the renewal of old housing stock has clearly intensified in the city centre since 1989 (Table 2). A significant part of the old housing stock has been largely (30\%) or partially (59\%) renovated since 1989 . Dwellings that were partially renovated have at least a renewed bathroom, or shower and toilet inside, as well as a modern heating system. Only 11 percent of the old housing stock has not been subject to any kind of renovation or just to a very limited extent. The level of renovation is generally highest in that segment of the owner occupied sector that was obtained by purchase on the free market. However, our data indicated the presence of upgrading not only in the owner occupied sector but to a smaller extent also in the public housing sector.

To conclude, residential renovations show significant variations in the inner city of Budapest not only in space, but also according to tenure, which in turn leads to a heterogeneous pattern as far as the residential environment, price level and consequently prestige are concerned. The majority of old dwellings have been renovated, but a distinctly luxury segment on the housing market is not recognisable (Zischner 2013).

\subsection{Social factors}

Inner-city transformations are very much related to societal changes. They include among others socio-economic differentiation, changes in lifestyle, demographic changes or new waves of residential mobility. In the light of the classical gentrification concept in our Budapest case-study areas newly built dwellings and owner occupied dwellings put on the market could provide access for newcomers and enable displacement. Our survey showed that 41 percent of respondents moved to his/her dwelling between 2000 and 2006, another 21 percent during the $1990 \mathrm{~s}$. Long-term residents, those who had lived in the neighbourhood before 1990, were in minority though with relatively high proportion (38\%). We can say that in the time of our survey newcomers and long-term residents were relatively mixed in the case-study areas.

1 The role of private rental sector is traditionally very limited. 
Social changes and social upgrading can be best traced by changes in the socio-economic status of residents. According to survey data the group of newcomers is much younger and better educated than long-term residents and they live mostly in household-types that are common among young adults (singles, young couples with or without children, flat-sharing communities). Regarding the level of income newcomers also tend to be better off but not extremely and exclusively, households with average and below average income have also substantial shares among the new residents. Overall, we found a rather heterogeneous social pattern and a good mix of different social groups in the case-study areas, which corresponds to the highly diversified local housing stock as far as the age, size, quality and tenure of dwellings are concerned. Thanks to the mixed housing stock the investigated neighbourhoods remained accessible for very diverse population groups, even though lower income groups had clearly limited access to the high-end segment of the newly built dwellings, and some parts of the owner occupied dwellings (generally the larger units). Regarding residential mobility swift displacement of long-term residents and robust gentrification remained limited in some smaller pockets of poverty where state-led regeneration programmes were carried out. In these neighbourhoods (e.g. Ferencváros, Józsefváros) large-scale demolitions also took place including local government actions to disperse low-income marginalised groups (especially the Roma) into other districts of Budapest or even beyond the city boundaries.

Social indices provide limited information why newcomers decide to move to a certain area and why long-term residents decide to stay in place (residential preferences and motivations), therefore, the question arises whether the easily detectable socio-demographic changes in Budapest inner city are also coupled with socio-cultural changes where newcomers are more inner-city orientated according to their housing preferences and lifestyle. Based on the survey results we can say that the great majority (over $80 \%$ ) of our sample living in the casestudy quarters follow an "active-urban lifestyle", which means that they highly esteem the inner-city building stock and ambience of their neighbourhood and/ or they are closely attached to the inner city regarding their leisure activities and consumption. Residents following "active-urban lifestyle" can be divided into two sub-groups: "traditionalists" who put more emphasis on the architectural qualities of the inner city, and "post-modernists" (or "bohemians") who esteem highly both the inner-city housing quality and the leisure and cultural facilities offered by these quarters. The attachment to inner-city housing is the strongest among "post-modernists" (Zischner 2013).

As opposed to residents with "active-urban lifestyle" some part of the local population can be labelled as "passive-urban" as far as their lifestyle is concerned, since their locational decision is not much determined by the historical values of the inner city or its leisure and cultural opportunities but more by pragmatic reasons, e.g. proximity to workplace, or to relatives. Consequently, their attachment to the neighbourhood is rather loose.

Our survey also indicated that socio-economic differences among residents in our survey areas were much stronger than the socio-cultural ones. Everyday life practices turned out to be very similar among the different socio-economic groups. E.g. the "active-urban lifestyle" population is dominant both in the 
group of long-term residents (71\%) and newcomers though with clearly increasing trends over time (83\% among residents settling there during the 1990s, and $88 \%$ among those after 2000). Also, long-term residents and elderly appreciate recent developments of urban renewal equally with younger households. These attitudes verify significant changes in the lifestyle of inner-city residents in Budapest compared to the previous results (e.g. Kovács, Wiessner 1999), where housing preferences of people living in the city-centre showed a strong desire towards single family homes in green environment at suburban locations.

Obviously, the general attitude of Budapest people towards inner-city living including the long-term residents of inner-city neighbourhoods changed significantly over time, this has also been demonstrated by others (Berényi, Szabó 2009). The dominance of "active-urban lifestyle" among both the newcomers and long-term residents imply that on the one hand, there is a significant demand among outsiders towards these neighbourhoods, and on the other hand, long-term local residents are increasingly aware of the advantages of their inner-city homes which hints at strengthening identity and social stability of these neighbourhoods. This is in line with earlier findings of papers focusing on urban transformation both in the western and eastern parts of Germany where changes in lifestyle and residential preferences contributed significantly to the upgrading and stabilisation of inner-city neighbourhoods (Klee 2001; Zischner 2003; Dörfler 2010; Twickel 2010). We think that the growing prestige of innercity neighbourhoods due to reinvestments, the changing lifestyle and housing preferences of people and the strengthening identity of local residents with their neighbourhood play important role in the renewal and social stabilisation of inner-city quarters in Budapest.

\section{Development trajectories of inner-city neighbourhoods in Budapest}

In the conceptual part of this paper we characterised gentrification as a "catch all term", that has been used in many different contexts and for very different forms of physical and/or social upgrading in urban (and most recently rural) areas. However, the use of the broad concept of gentrification can often result in the original content of the process referring to qualitative changes in an urban neighbourhood getting lost. Our empirical findings also confirmed that there is a great variety of renewal and upgrading process in Budapest inner city as far as the role and strategy of local districts, the quality of housing stock, or the influencing social factors are concerned. If all these renovations are uniformly called gentrification, then the essence of these multi-faceted processes would get lost. Therefore, in the remaining part of the paper we try to generalise the results of our research with special attention to the distinct variations of the process. Hence, the term gentrification will only be used in cases of high-quality renovation of the physical environment, followed by the influx of affluent population with "active urban lifestyle" generating massive displacement of long-term residents. Altogether we could identify the following types of urban renewal and neighbourhood change in our case-study areas (Zischner 2013): 
- gentrification (both physical and social upgrading according to the classical definition)

- incumbent upgrading (physical upgrading by long-term residents)

- soft forms of revitalisation (physical upgrading, influx of people with "activeurban lifestyle" but not necessarily with high income).

What is remarkable, that these forms of neighbourhood changes intermix in all our seven case-study areas, though with different intensity.

\subsection{Gentrification}

Depending on the attitude and role of the public sector, whether local governments actively participate in programmes designed to enhance neighbourhood regeneration or they are rather passive, two distinct forms of gentrification: "strategic" and "unplanned" can be distinguished in downtown Budapest. The trajectory of "strategic gentrification" (or "organised gentrification" according to Kovács 2009) starts with an utterly deprived and run-down neighbourhood, where privatisation of housing remained limited, the local government is the biggest landlord (Fig. 4). The vast number of run-down buildings as well as abundant empty plots and abandoned areas provide the local district a good opportunity to carry out regeneration programmes including demolitions, new constructions and renovations. Crucial in the emergence of "strategic gentrification" is demolition and the subsequent mass construction of high-quality housing attracting affluent people with active urban lifestyle to the area. This process concentrates exclusively in heavily disinvested quarters; it is sustained by massive public subsidy and control, and produces the most abrupt population change (gentrification) with the active participation of the local neoliberal state.

As an opposite, the process of "unplanned gentrification" evolves in neighbourhoods where the physical and social upgrading is not so much driven by the active policy of local government but rather by the investments of the

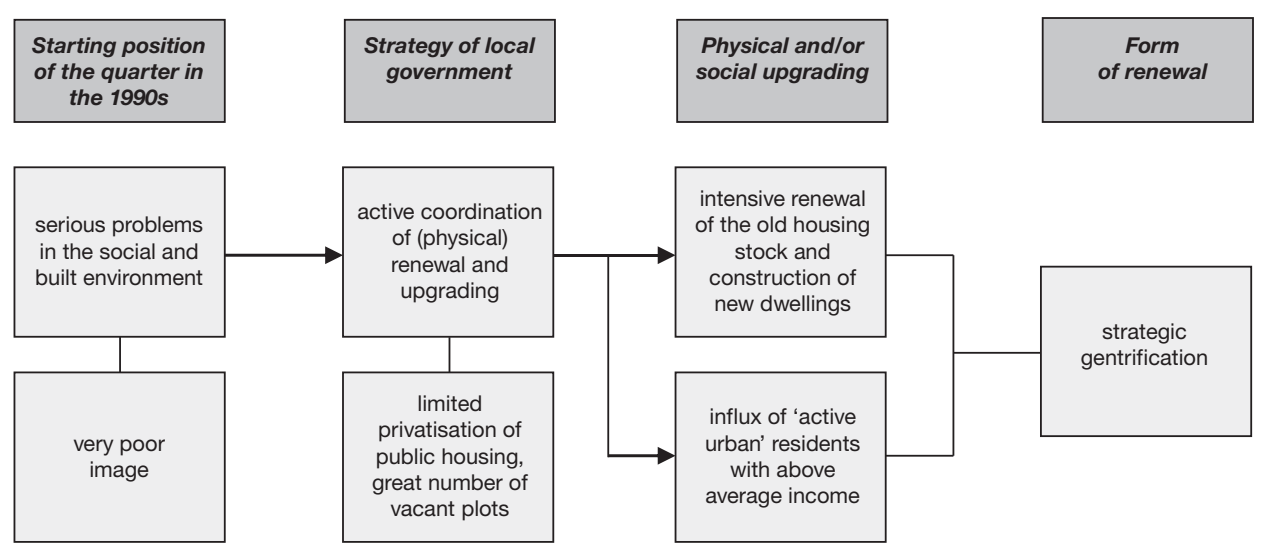

Fig. 4 - Trajectory of "strategic gentrification”. Source: Zichner (2013). 


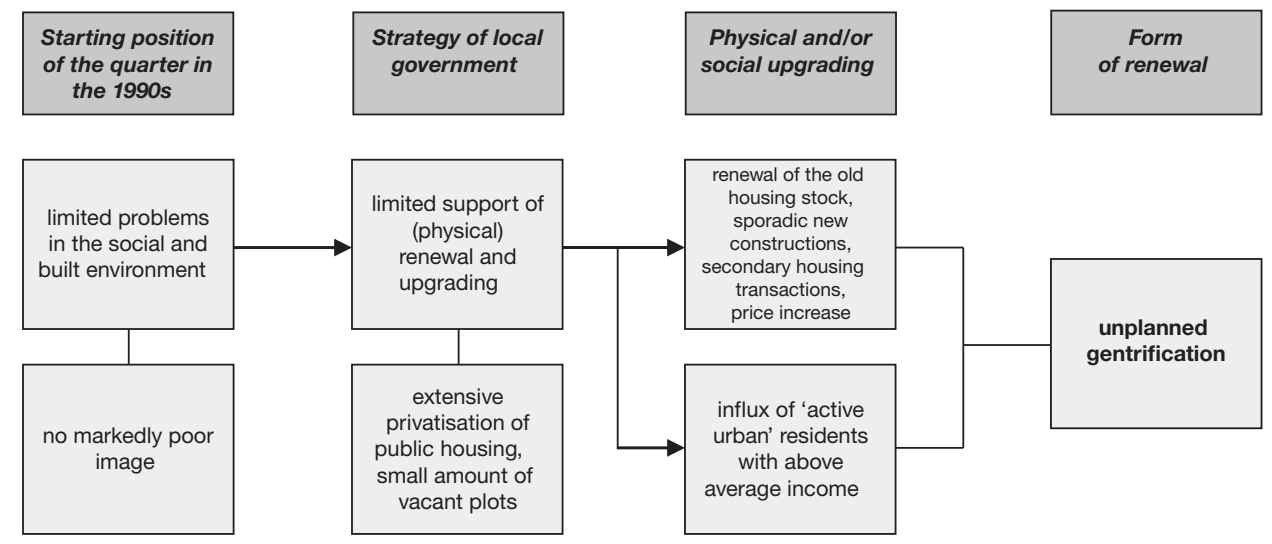

Fig. 5 - Trajectory of “unplanned gentrification”. Source: Zichner (2013).

private sector or owner-occupiers (Fig. 5). In the emergence of "unplanned gentrification" secondary housing transactions play an important role and enable the influx of affluent residents. In this case the role of new housing construction, which occurs sporadically, is rather limited and the pace and extent of population displacement is also lower. This type of gentrification occurs in less deprived neighbourhoods with close to city centre location and modest socio-economic status.

\subsection{Incumbent upgrading}

In the case of incumbent upgrading dwellings and buildings acquired through privatisation are usually renovated (Fig. 6). They are inhabited further on by the former tenant (i.e. new owner). The process is especially common

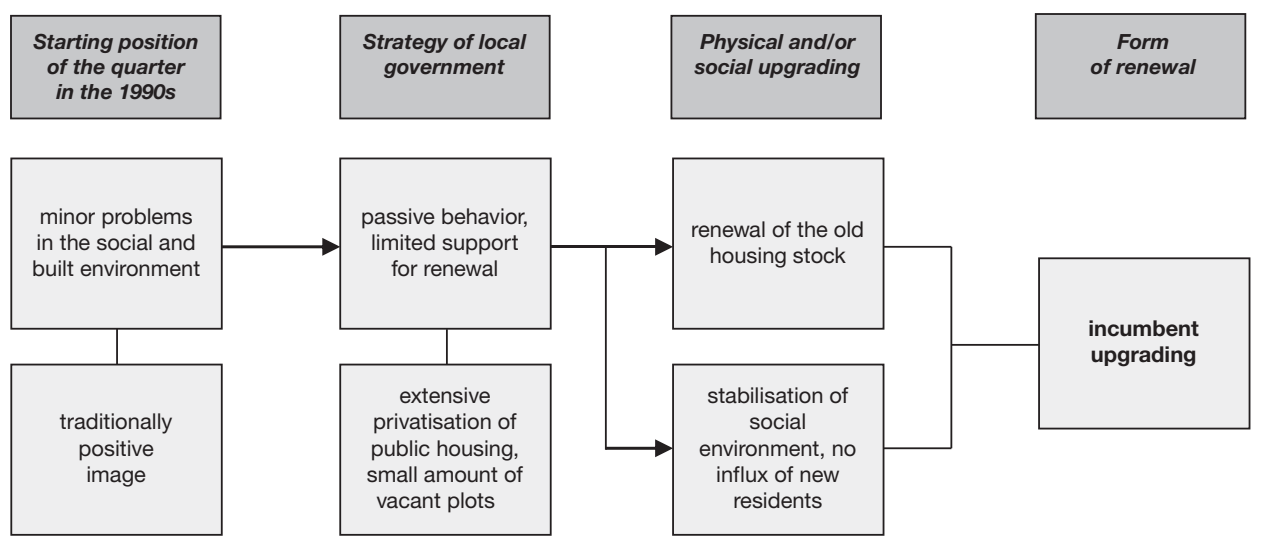

Fig. 6 - Trajectory of “incumbent upgrading”. Source: Zichner (2013). 


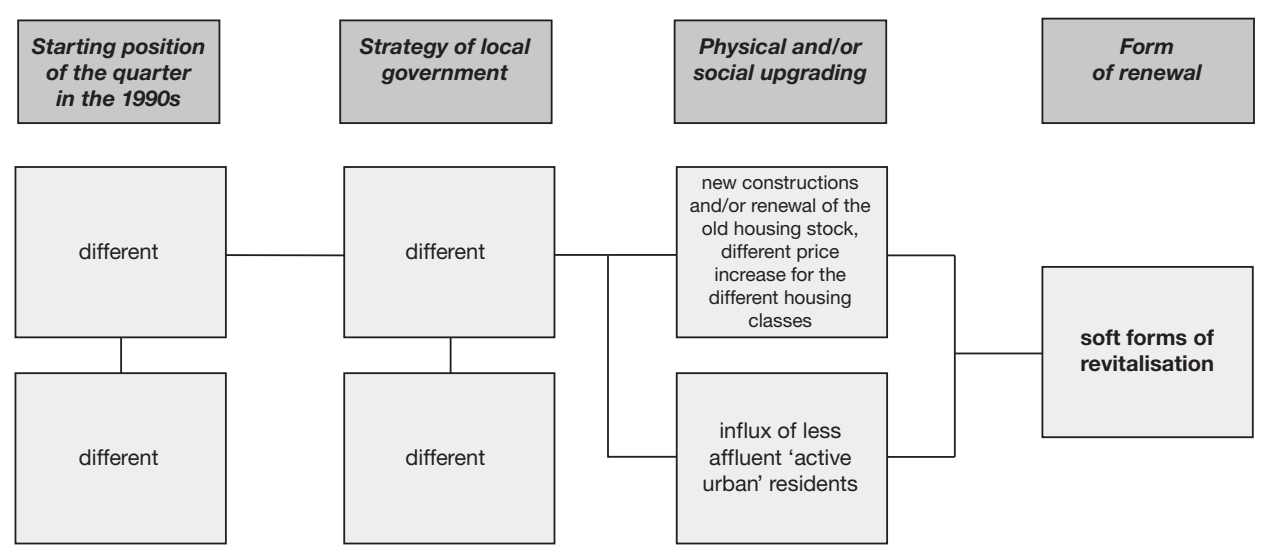

Fig. 7 - Trajectory of "soft forms of revitalisation”. Source: Zichner (2013).

in quarters where extensive privatisation took place in the early 1990s and where the share of long-term residents is relatively high compared to other neighbourhoods. In such areas the renewal of dwellings is hardly supported by the local government, the status of local people is generally higher compared to stigmatised neighbourhoods, and upgrading is coupled with social stability and cohesion.

\subsection{Soft forms of revitalisation}

Soft forms of revitalisation in Budapest are very much comparable with "soft gentrification" or "controlled gentrification", described for the upgrading processes of East German cities where the drastic displacement of long-term residents could hardly evolve (see e.g. Hill, Wiest 2004; Wiest, Zischner 2006). In this case physical upgrading and social change are also taking place, however, the influx of affluent middle-class population and the displacement of long-term residents is limited, thus, according to our understanding the process cannot be labelled as true gentrification. Changes in the social milieu of the neighbourhood are rather modest and caused by the arrival of very heterogeneous social groups with more moderate income than those moving to gentrifying areas (Fig. 7). This type of development is present (and often dominant) in all our case-study areas. However, soft forms of revitalisation in downtown Budapest are widespread not because of the high vacancy rate on the housing market (dominated by private rentals) and large-scale public subsidies like in East Germany, but mainly due to the dominance of owner occupation and direct control of the districts' local government.

New residents arrive to the area either through secondary housing transactions where the dwellings are not fully renovated, thus, they are sold at a reasonable price, or through new constructions where the size of dwellings is relatively small. In both cases housing is affordable for the less affluent but still "active urban" strata (e.g. young couples with or without children). 


\section{Conclusions}

The renewal of the built environment has become a dominant process in the inner city of Budapest after decades of neglect and decay caused by the communist system. Striking is the enormous diversity and complexity of upgrading processes which is reflected, on the one hand, by the growing heterogeneity of the housing stock both in terms of quality and size, and on the other hand, the emerging new social mix, as a result of the influx of rather heterogeneous social groups that coexist with long-term residents. Spatially, it has also been demonstrated that neighbourhood renewal is present in many distinct forms scattered in the inner city, though there are also neighbourhoods that have been affected by disinvestment and further deprivation since the systemic changes.

On the basis of our multi-dimensional analysis where political, economic and social reasoning of the upgrading as well as its local contexts were equally taken into consideration we could define three main types of upgrading: gentrification (with two variants), incumbent upgrading and soft forms of revitalisation. The neighbourhoods we studied cannot be characterised only by one of these types, more common is a variation of these developments leading to "diversified upgrading". This finding challenges the extensive use of a chaotic concept of gentrification. Similarly to other western metropolises (Criekingen, Decroly 2003) the inner-city neighbourhoods in Budapest are being reshaped by several distinct processes and not by a single gentrification process. Our findings also confirm that local policy measures have significant influence on the process of urban renewal. In this respect the role of privatisation of local public housing sector and the highly differentiated renewal strategies of local districts should be emphasised.

It was also found that since the housing market of Budapest is dominated by owner-occupied housing this system provides easy access to the inner city for very diverse social groups and not just the financially strong "gentrifiers". This is crucial with regards the possibility of residential displacement and gentrification, and the sustainability of a healthy social mix what has recently been emphasised in the literature (see Musterd, Andersson 2005; van Kempen, Bolt 2009).

On the demand side substantial changes occurred regarding the lifestyle and housing preferences of residents especially if compared to the 1990s when the dream for many Budapest residents was a single-family home at suburban location (Kok, Kovács 1999; Timár, Váradi 2001; Tosics 2005). In this respect socio-cultural changes and re-orientation towards inner-city milieu within the mainstream society seem to be the main reason for the increasing popularity and demand towards renovated inner-city dwellings. Our findings, thus, imply that in future research on urban renewal and gentrification in post-socialist cities more emphasis should be placed on the socio-cultural changes on the demand side of the housing market and the multidimensional nature of the upgrading processes. We also think that the term "gentrification" should in the future be applied only for those cases where the original criteria (i.e. higher level upgrading with displacement) are met, in order to better accentuate the heterogeneity and diversity of inner-city upgrading processes in post-socialist cities. 


\section{References:}

ATKINSON, R., BRIDGE, G., eds. (2005): Gentrification in a Global Context. The new urban colonialism. Routledge, London.

BADYINA, A., GOLUBCHIKOV, O. (2005): Gentrification in central Moscow: A market process or a deliberate policy? Money, power and people in housing regeneration in Ostozhenka, Geografiska Annaler B 87, pp. 113-129.

BARTA, G., BELUSZKY, P., CZIRFUSZ, M., GYŐRI, R., KUKELY, G. (2006): Rehabilitating the Brownfield Zones of Budapest. Centre for Regional Studies, Hungarian Academy of Sciences. Discussion Papers, 51. Pécs.

BEAUREGARD, R.A. (1986): The Chaos and Complexity of Gentrification. In: Smith, N., Williams, P. (eds.): Gentrification of the city. Allen \& Unwin, Boston, pp. 35-55.

BELUSZKY, P., TIMÁR, J. (1992): The changing political system and urban restructuring in Hungary, Tijdschrift voor Economische en Sociale Geografie, 83, No. 5, pp. 380-390.

BERÉNYI, B.E., SZABÓ, B. (2009): Housing preferences and the image of inner city neighborhoods in Budapest, Hungarian Geographical Bulletin, 58, No. 3, pp. 201-214.

BERNT, M., HOLM, A. (2005): Exploring the substance and style of gentrification: Berlin's "Prenzlberg": In: Atkinson, R., Bridge, G. (eds.): Gentrification in a Global Context. The new urban colonialism, Routledge, London, pp. 106-120.

BERNT, M., HOLM, A. (2009): Is it, or is it not? The conceptualisation of gentrification and displacement and its political implications in the case of Berlin-Prenzlauer Berg, CITY Special Issue. Cities for People, Not for Profit, 13, No. 2-3, pp. 312-324.

BRECKNER, I. (2010): Gentrifizierung im 21. Jahrhundert, Aus Politik und Zeitgeschichte, 17, pp. 27-32.

CARPENTER, J., LEES, L. (1995): Gentrification in New York, London and Paris: An International Comparison, International Journal of Urban and Regional Research, 19, No. 2, pp. 286-303.

CLAY, P.L. (1979): Neighbourhood Renewal. Middle-Class Resettlement and Incumbent Upgrading in American Neighborhoods. Lexington Books, Lexington.

DANGSCHAT, J.S. (1988): Gentrification: Der Wandel innenstadtnaher Wohnviertel. In: Friedrichs, J. (ed.): Soziologische Stadtforschung, Kölner Zeitschrift für Soziologie und Sozialpsychologie Sonderheft, No. 29, Opladen, pp. 272-292.

DAVIDSON, M., LEES, L. (2005) New-build "gentrification" and London's riverside renaissance, Environment and Planning A, 37, No. 7, pp. 1165-1190.

DAVIDSON, M., LEES, L. (2010): New-Build Gentrification: Its Histories, Trajectories, and Critical Geographies, Population, Space and Place. Special Issue: New Forms of Gentrification, 16, No. 5, pp. 395-411.

DÖRFLER, T. (2010): Gentrification in Prenzlauer Berg? Milieuwandel eines Berliner Sozialraumes seit 1989, Bielefeld.

DÖVÉNYI, Z., KOVÁCS, Z. (2006): Budapest: Post-socialist metropolitan periphery between "catching up" and individual development path. European Spatial Research and Policy, 13, No. 2, pp. 23-41.

FÖLDI, Zs. (2006): Neighbourhood dynamics in inner-Budapest: a realist approach. Netherlands Geographical Studies No. 350, Faculty of Geosciences, University of Utrecht.

FÖLDI, Zs., VAN WEESEP, J. (2007): Impacts of Globalisation at the Neighbourhood Level in Budapest, Journal of Housing and the Built Environment, 22, No. 1, pp. 33-50.

FRIEDRICH, K. (2000): Gentrifizierung. Theoretische Ansätze und Anwendung auf Städte in den neuen Ländern, Geographische Rundschau, 52, No. 7-8, pp. 34-39.

FRIEDRICHS, J. (1996): Gentrification. Forschungsstand und Methodologische Probleme. In: Friedrichs, J., Kecskes, R. (eds.): Gentrification. Theorie und Forschungsergebnisse, Leske \& Budrich, Opladen, pp. 13-40.

FRIEDRICHS, J., HÄUSSERMANN, H. (2001): Die Entwicklung der Städte in den neuen Bundesländern. In: Bertram, H., Kollmorgen, R. (eds): Die Transformation Ostdeutschlands. Berichte zum sozialen und politischen Wandel in den neuen Bundesländern, Leske \& Budrich, Opladen, pp. 315-339. 
GLASS, R. (1964): Aspects of Change. In: Centre for Urban Studies (ed.): London. Aspects of Change. Center for urban studies report, No. 3, pp. xviii-xix.

GLATTER, J. (2007): Gentrification in Ostdeutschland: untersucht am Beispiel der Dresdner Äußeren Neustadt. Dresdner Geographische Beiträge No. 11, Dresden, 233 pp.

GÓRCZYNSSKA, M. (2014): Unique or universal? Mechanisms and processes of social change in post-socialist Warsaw, Hungarian Geographical Bulletin, 63, No. 3, pp. 255-270.

HAMMEL, D.J. (2009): Gentrification. In: Kitchin, R., Thrift, N. (eds): International Encyclopedia of Human Geography, 4, Elsevier, Oxford, pp. 360--367.

HAMNETT, C., RANDOLPH, B. (1986): Tenurial Transformation and the Flat Break-up Market in London: The British Condo Experience. In: Smith, N., Williams, P. (eds.): Gentrification of the City. Allen \& Unwin, Boston, pp. 121-152.

HEGEDÜS, J., TOSICS, I. (1991): Gentrification in Eastern Europe: The case of Budapest. In: van Weesep, J., Musterd, S. (eds): Urban Housing for the Better-Off: Gentrification in Europe Stedelijke Netwerken, Utrecht, pp. 124-136.

HEGEDÜS, J., TOSICS, I. (1994): Privatisation and Rehabilitation in the Budapest Inner Districts. Housing Studies, 9, No. 1, pp. 39-54.

HILL, A., WIEST, K. (2004): Gentrification in ostdeutschen Cityrandgebieten? Theoretische Überlegungen zum empirischen Forschungsstand, Berichte zur deutschen Landeskunde, 78 No. 1, pp. 25-39.

HOLM, A. (2006): Die Restrukturierung des Raumes. Stadterneuerung der 90er Jahre in Ostberlin: Interessen und Machtverhältnisse. Transcript Verlag, Bielefeld, 352 pp.

KARSTEN, L. (2003): Family Gentrifiers: Challenging the City as a Place Simultaneously to Build a Career and to Raise Children. Urban Studies, 40, No. 12, pp. 2573-2584.

KAUKO, T. (2007): An Analysis of Housing Location Attributes in the Inner City of Budapest, Hungary, Using Expert Judgments, International Journal of Strategic Property Management, 11, No. 4, pp. 209-225.

KLEE, A. (2001): Der Raumbezug von Lebensstilen in der Stadt: Ein Diskurs über eine schwierige Beziehung mit empirischen Befunden aus der Stadt Nürnberg. L.I.S.-Verlag, Passau, 236 pp.

KOK, H., KOVÁCS, Z. (1999): The process of suburbanization in the agglomeration of Budapest. Netherlands Journal of Housing and the Built Environment, 14, No. 2, pp. 119-141.

KOVÁCS, Z. (1998): Ghettoization or gentrification? Post-socialist scenarios for Budapest. Netherlands Journal of Housing and the Built Environment, 13, No. 1, pp. 63-81.

KOVÁCS, Z. (2009): Social and economic transformation of historical neighbourhoods in Budapest. Tijdschrift voor Economische en Sociale Geografie, 100, No. 4, pp. 399-416.

KOVÁCS, Z. (2012): Residential segregation in Budapest before and after transition. In: Maloutas, T., Fujita, K. (eds.): Residential segregation in comparative perspective: making sense of contextual diversity. Ashgate, Aldershot, pp. 197-216.

KOVÁCS, Z., WIESSNER, R. (1999): Stadt- und Wohnungsmarktentwicklung in Budapest. Zur Entwicklung der innerstädtischen Wohnquartiere im Transformationsprozess. Beiträge zur Regionalen Geographie, No. 48, Institut für Länderkunde, Leipzig, 81 pp.

KOVÁCS, Z., WIESSNER, R., ZISCHNER, R. (2013): Urban renewal in the inner city of Budapest: Gentrification from a post-socialist perspective. Urban Studies, 50, No. 1, pp. 22-38.

KRIŠJĀNE, Z., BĒRZIN̦Š, M. (2014): Intra-urban residential differentiation in the post-Soviet city: the case of Riga, Latvia. Hungarian Geographical Bulletin, 63, No. 3, pp. 235-253.

LADÁNYI, J. (1993): Patterns of residential segregation and the Gypsy minority in Budapest. International Journal of Urban and Regional Research, 17, No. 4, pp. 30-41.

LADÁNYI, J. (2002): Residential Segregation among Social and Ethnic Groups in Budapest during the Post-communist Transition. In: Marcuse, P. van Kempen, R. (eds.): Of States and Cities. Oxford University Press, Oxford, pp. 170-182.

LEES, L. (1994): Gentrification in London and New York: An Atlantic Gap? Housing Studies 9, No. 2, pp. 199-217.

LEES, L. (2003): Super-gentrification: The Case of Brooklyn Heights, New York City. Urban Studies, 40, No. 12, pp. 2487-2509.

LEES, L., SLATER, T., WYLY, E. (2008): Gentrification. Routledge, New York. 310 pp.

LEY, D. (1980): Liberal Ideology and the Postindustrial City. Annals of the Association of American Geographers, 70, No. 2, pp. 238-258. 
LEY, D. (1981): Inner-City Revitalization in Canada: a Vancouver case study. Canadian Geographer, 25, No. 2, pp. 124-148.

LEY, D. (1996): The New Middle Class and the Remaking of the Central City. Oxford University Press, Oxford, 248 pp.

LEY, D. (2003): Artists, Aestheticisation and the Field of Gentrification. Urban Studies, 40, No. 12 , pp. 2527-2544.

MARZIŃCZAK, S. (2012): The evolution of spatial patterns of residential segregation in Central European cities: The Łódź functional urban region from mature socialism to mature post-socialism. Cities, 29, No. 5, pp. 300-309.

MURZYN, M. (2006): "Winners" and "Losers" in the Game: the Social Dimension of Urban Regeneration in the Kazimierz Quarter in Krakow. In: Enyedi, G., Kovács, Z. (eds.): Social Changes and Social Sustainability in Historical Urban Centres. Centre for Regional Studies, Hungarian Academy of Sciences, Pécs, pp. 81-106.

MUSTERD, S., OSTENDORF, W., eds. (1998): Urban Segregation and the Welfare State. Routledge, London, $275 \mathrm{pp}$.

MUSTERD, S., ANDERSSON, R. (2005): Housing mix, social, mix and social opportunities. Urban Affairs Review, 40, No. 6, pp. 761-790.

PHILLIPS, M. (1993): Rural Gentrification and the Processes of Class Colonisation. Journal of Rural Studies, 9, No. 2, pp. 123-140.

PHILLIPS, M. (2002): Distant bodies? Rural studies, political-economy and poststructuralism. Sociologia Ruralis, 42, No. 2, pp. 81-105.

PHILLIPS, M. (2005): Differential productions of rural gentrification: illustrations from North and South Norfolk. Geoforum, 36, No. 4, pp. 477-494.

RÉRAT, P., LEES, L. (2011): Spatial capital, gentrification and mobility: evidence from Swiss core cities. Transactions of the Institute of British Geographers, 36, No. 1, pp. 126-142.

RÉRAT, P., SÖDERSTRÖM, O., PIGUET, E. (2010): New Forms of Gentrification: Issues and Debates. Population, Space and Place, 16, No. 5, pp. 335-343.

ROSE (1996) Economic restructuring and the diversification of gentrification in the 1980s: a view from a marginal metropolis. In: Caulfield, J., Peake, L. (eds.): City Lives and City Forms: Critical Research and Canadian Urbanism. University of Toronto Press, Toronto, pp. 131-172.

SMITH, N. (1979): Toward a Theory of Gentrification A Back to the City Movement by Capital, not People. Journal of the American Planning Association, 45, No. 4, pp. 538-548.

SMITH, N. (1996): The New Urban Frontier: Gentrification and the Revanchist City. Routledge, London, $288 \mathrm{pp}$.

STANDL, H., KRUPICKAITE, D. (2004): Gentrification in Vilnius (Lithuania) - the Example of Uzupis. Europa Regional 12, No. 1, pp. 42-51.

SÝKORA, L. (1999): Changes in the internal spatial structure of post-communist Prague. GeoJournal 49, No. 1, pp. 79-89.

SÝKORA, L., BOUZAROVSKI, S. (2012): Multiple transformations: Conceptualising the post-communist urban transition. Urban Studies, 49, No. 1, pp. 43-60.

TIMÁR, J., VÁRADI, M.M. (2001): The uneven development of suburbanization during transition in Hungary. European Urban and Regional Studies, 8, No. 4, pp. 349-360.

TOSICS, I. (2005): The post-socialist Budapest: the invasion of market forces and the attempts of public leadership. In: Hamilton, F.E.I., Dimitrowska-Andrews, K., Pichler-Milanovic, N. (eds): Transformation of Cities in Central and Eastern Europe: Towards Globalization. United Nations University Press, Tokyo, pp. 248-280.

TOSICS, I. (2006): Spatial restructuring in post-socialist Budapest. In: Tsenkova, S., NedovicBudic, Z. (eds): The Urban Mosaic of Post-Socialist Europe: Space, Institutions and Policy. Physica-Verlag, Heidelberg, pp. 131-150.

TWICKEL, C. (2010): Gentrifidingsbums oder eine Stadt für alle. Ed. Nautilus, Hamburg, 128 pp.

VAN CRIEKINGEN, M., DECROLY, J.-M. (2003) Revisiting the diversity of gentrification: Neighbourhood renewal processes in Brussels and Montreal. Urban Studies, 40, No. 12, pp. 2451-2468.

VAN KEMPEN, R., BOLT, G. (2009): Social cohesion, social mix, and urban policies in the Netherlands. Journal of Housing and the Built Environment, 24, No. 4, pp. 457-475. 
WEISKE, C. (1996): Gentrification und Incumbent Upgrading in Erfurt. In: Friedrichs, J., Kecskes, R. (eds.): Gentrification. Theorie und Forschungsergebnisse. Leske \& Budrich, Opladen, pp. 193-226.

WIEST, K., ZISCHNER, R. (2006): Aufwertung innerstädtischer Altbaugebiete in den neuen Bundesländern - Prozesse und Entwicklungspfade in Leipzig. Deutsche Zeitschrift für Kommunalwissenschaften, 45, No. 1, pp. 99-121.

WIESSNER, R. (1987): Wohnungsmodernisierungen - Ein behutsamer Weg der Stadterneuerung? Empirische Fallstudie in Altbauquartieren des Nürnberger Innenstadtrandgebiets. Münchner Geographische Hefte 54, Kallmünz, 278 pp.

WIESSNER, R. (1988): Probleme der Stadterneuerung und jüngerer Wohnungsmodernisierung in Altbauquartieren aus sozialgeographischer Sicht. Mit Beispielen aus Nürnberg, Geographische Rundschau, 40, No. 11, pp. 18-25.

WIESSNER, R., ZISCHNER, R. (2010): Revitalisierung großstädtischer Wohnquartiere und ihre sozialen Implikationen: Fallbeispiele aus Budapest. In: Kunze, C. (ed.): Wirtschaftlicher Aufholprozess und EU-Integration in Mittel- und Osteuropa - das europäische Wachstumsmodell in der Krise? Leipzig (= Transformation). Leipziger Beiträge zur Wirtschaft und Gesellschaft 27/28, pp. 159-177.

ZISCHNER, R. (2003): Gentrification in Leipzig-Connewitz? Theoretische GentrificationAnsätze und deren Gültigkeit in Städten der neuen Bundesländer. Thesis. Institut für Geographie Universität Leipzig, Leipzig, 184 pp.

ZISCHNER, R. (2013): Zur Frage der Gentrification in Städten Mittel- und Osteuropas - das Fallbeispiel Budapest. Innerstädtische Wohnquartiere von Budapest im baulichen und sozialen Wandel. Dissertation. Institut für Geographie Universität Leipzig. Leipzig, 262 pp.

ZUKIN, S. (1982): Loft living as "historic compromise" in the urban core: the New York experience. International Journal of Urban and Regional Research, 6, No. 2, pp. 256-267.

\section{Shrnutí}

\section{ZA HRANICI GENTRIFIKACE: RŮZNÉ FORMY LOKÁLNÍ MODERNIZACE VE VNITROMĚSTSKÝCH OBLASTECH BUDAPEŠTI}

K zřejmě nejviditelnějším a nejnáhlejším změnám dochází v samotném centru post-socialistických měst, kde pobíhá soutěž o místo mezi investory, developery a movitými obyvateli nejintenzivněji. Článek staví na výsledcích empirického výzkumu vnitřního města Budapešti, na kterém byl koncept gentrifikace testován v kontextu post-socialistického města. Mechanismy renesance vnitřního města jsou analyzovány s ohledem na působení tří klíčových skupin aktérů: politických činitelů, investorů a obyvatel. Článek je rozdělen do pěti částí. První část se věnuje konceptu gentrifikace a jeho uplatnitelnosti v kontextu post-socialistických měst. Ve druhé části je představena použitá metodologie. Třetí část se pak soustředuje na faktory ovlivňující městskou obnovu v centru Budapešti. Čtvrtá část článku představuje typologii procesu obnovy města a poslední kapitola shrnuje hlavní poznatky a nastiňuje další možné výzkumné otázky.

Podle našeho konceptuálního rámce (obr. 1) lze vývoj obytného prostředí v post-socialistických městech nejlépe vysvětlit pomocí konfigurace tří propojených faktorů: politického, ekonomického a společenského. Jejich úloha se může lišit v různých městech či jejich částech, nicméně při zkoumání různých prvků obnovy města v post-socialistických městech je potřeba mít na zřeteli každý z trojice faktorů.

Výsledky empirického výzkumu potvrdily, že v Budapešti se odehrává celá řada procesů spojených s obnovou nebo revitalizací, u nichž se rozdílným způsobem projevují funkce a strategie městských administrativ, kvalita obytné zástavby nebo vliv sociálních faktorů. Na základě multidimenzionální analýzy se nám podařilo identifikovat tři typy revitalizace: klasickou gentrifikaci (která se dále dělí na dva druhy), revitalizaci silami bydlících obyvatel, a „měkké“ formy revitalizace. Podle přístupu a role veřejného sektoru a účasti lokálních administrativ na programech městské regenerace lze odlišit dvě formy gentrifikace v Budapešti: „strategickou“ a „neplánovanou“. Trajektorie strategické gentrifikace začíná u kompletně 
deprivovaných městských oblastí kde místní samospráva vlastní většinu pozemků, úroveň privatizace je nízká a početné prázdné pozemky a zchátralé stavby nabízí dobrou příležitost pro regenerační aktivity včetně potřebných demolic a renovací. Pro vznik strategické gentrifikace je klíčvá právě možnost rozsáhlých demolic a následná výstavba kvalitních obytných staveb, které dokážou přilákat zabezpečené zájemce s aktivním životním stylem. Oproti tomu proces neplánované gentrifikace se rozvíjí v oblastech, kde zlepšení sociální úrovně a fyzického vzhledu obytného prostředí není hnáno aktivní politikou místní administrativy, ale vychází z nezávislých investic soukromého sektoru či snah majitelů nemovitostí. $\mathrm{V}$ př́ípadě neplánované gentrifikace hrají významnou roli sekundární transakce a úloha nových stavebních projektů, kterých zpravidla nevzniká mnoho, je omezená stejně jako míra a intenzita populačního přesunu.

V případě procesu revitalizace silami bydlících obyvatel (tedy vnitřního zlepšování) dochází zpravidla $\mathrm{k}$ renovaci obytných staveb získaných během privatizace. Ty jsou pak dále obývány původními rezidenty, ted již majiteli. Tento proces je obzvlášt běžný ve čtvrtích, kde počátkem devadesátých let došlo $\mathrm{k}$ rozsáhlé privatizaci a kde se udržuje (oproti ostatním městským částem) vysoký podíl stálých obyvatel. V takových oblastech je zpravidla role místní administrativy v regeneračním úsilí minimální, status obyvatel je obecně vyšší, než je tomu v případě stigmatizovaných komunit, a revitalizace je spojena se sociální stabilitou a kohezí.

„Měkké“ formy revitalizace se v Budapešti velmi podobají „měkké gentrifikaci“ nebo „kontrolované gentrifikaci“, popisované ve městech bývalého východního Německa, kde se radikální relokace původních obyvatel městských center neměla šanci rozvinout. I v tomto případě dochází ke zlepšení fyzického prostředí a sociálním změnám, nicméně příchod movitých členů střední třídy a odchod původních obyvatel je v tomto případě ještě více omezen. Proto lze tento proces jen těžko označit za skutečnou gentrifikaci. Změny v sociálním prostředí jsou skromné a jejich nositeli jsou spíše heterogenní skupiny příchozích s více průměrnými příjmy, než bývá obvyklé u gentrifikovaných oblastí.

Zkoumané čtvrti nelze charakterizovat pouze jedním z těchto procesů, nebot̉ zmiňované trajektorie vytvářejí různé varianty diverzifikované revitalizace. Gentrifikace se prostorově projevila pouze v chudobou těžce zasažených čtvrtích podstupujících regenerační programy organizované místní administrativou. Převládání „měkkých“ forem revitalizace je výrazně zapříčiněno mechanismy trhu s bydlením a plánovací funkcí místních administrativ, což umožňuje udržovat zdravé sociální prostředí i přes setrvalé regenerační úsilí. Největší podíl na budapeštském trhu s bydlením mají momentálně domy obývané jejich majiteli, což poskytuje lepší přístup do vnitroměstských oblastí širším skupinám obyvatel než jen finančně zabezpečeným nositelům gentrifikace. Tento poznatek je klíčový s ohledem na snahy o udržení zdravého sociálního prostředí a minimalizace negativních dopadů gentrifikace a vysídlování, na které stále více poukazuje i oborová literatura.

Obr. 1 -Konceptuální rámec lokálních změn v post-socialistických městech.

Obr. 2 -Analyzovaná oblast.

Obr. 3 -Úroveň fyzické obnovy obytných budov v centrálních zónách Budapešti, červenec 2005. Zdroj: mapový průzkum.

Obr. 4 -Trajektorie „strategické gentrifikace“.

Obr. 5 -Trajektorie „neplánované gentrifikace“.

Obr. 6 -Trajektorie revitalizace silami bydlících obyvatel.

Obr. 7 -Trajektorie „měkkých forem revitalizace“. 
Authors' affiliation: Z. Kovács: Institute of Geography, Research Centre for Astronomy and Earth Sciences, Hungarian Academy of Sciences and Department of Economic and Social Geography, University of Szeged, Hungary; e-mail: zkovacs@iif.hu. R. Wiessner, R. Zischner: Institute of Geography, University of Leipzig, Germany.

Initial submission, 2 July 2014; final acceptance 18 April 2015.

Please cite this article as:

KOVÁCS, Z., WIESSNER, R., ZISCHNER, R. (2015): Beyond gentrification: Diversified neighbourhood upgrading in the inner city of Budapest. Geografie, 120, No. 2, pp. 251-274. 